\title{
DAMPAK PENDIDIKAN KEAKSARAAN FUNGSIONAL TERHADAP PENINGKATAN KUALITAS HIDUP SOSIAL EKONOMI \\ DI DESA PARADO WANE KECAMATAN PARADO KABUPATEN BIMA
}

\author{
Oleh :Ariani Rosadi \\ (Program Studi Ilmu Komunikasi STISIP Mbojo Bima)
}

\begin{abstract}
ABSTRAK
Pendidikan keaksaraan, merupakan bentuk layanan Pendidikan Non Formal (PNF) untuk membelajarkan masyarakat buta aksara, agar memiliki keterampilan baca tulis hitung, dan kemampuan fungsional untuk meningkatkan "mutu"dan "taraf " hidupnya. Keaksaraan dapat didefinisikan sebagai salah satu bentuk layanan Pendidikan Non Formal (PNF) bagi masyarakat yang belum memilikikemampuan ca-lis-tung, dan setelah mengikuti program ini (hasil belajarnya) mereka memiliki kemampuan "membaca menulis dan berhitung, mendengarkan dan berbicara" dalam bahasa Indonesia serta menggunakan / berfungsi bagi kehidupannya. Artinya merekatidak hanya memiliki kemampuan keaksaraan dan keterampilan atau bermata pencaharian saja, tetapi juga dapat survivedalam dunia kehidupannya.Penelitian ini bertujuan untuk mengetahui dampak pendidikan keaksaraan fungsional terhadap kualitas hidup sosial ekonomi, studi pada masyarakat Desa Parado Wane Kecamatan Parado Kabupaten Bima.Jenis peneliti yang digunakan dalam peneliti ini adalah : 1) Pamong belajar Pusat Kegiatan Belajar Masyarakat (PKBM) NTB, 2) Pengelola PKBM Desa Parado Wane, 3) Tutor PKBM, 4) Warga belajar di Pemerintahan Desa, Kepala Desa/staf Desa Parado Wane. Dalam rangka pengumpulan data ini dalam penelitian ini menggunakan metode observasi, metode interviewatau teknik pengumpulan data dengan menggunakan indera manusia disertai dengan pencatatan secara sistematik penyelidiklangsung mendatangi sasaran-sasaran penyelidiknya, mendengar, melihat serta membuat catatan-catatan. Metode interview disebut juga dengan wawancara atau kuesioner lisan yaitu sebuah dialog yang dilakukan oleh pewawancara untuk memperoleh keterangan-keterangan atau informasi dari data usaha atau catatancatatan tentang masalah-masalah atau peristiwa lalu.
\end{abstract}

Keyword: Keaksaraan Fungsional, kualitas hidup sosial ekonomi.

\section{PENDAHULUAN}

\section{A. Latar Belakang}

Salah satu aspek yang menentukan tinggi rendahnya sumber daya manusia dapat diukur melalui tingkat keaksaraan penduduknya. Oleh karena itu tingkat keaksaraan suatu negara sangat menentukan dalam pembangunan manusia yang nantinya merupakan salah satu indikator untuk menetapkan indeks pengembangan Sumber Daya Manusia (SDM) atau Human Development Indext (HDI). 
Buta aksara merupakan salah satu masalah Nasional yang sampai saat ini tetap menjadi perhatian pemerintah untuk penuntasannya, karena program pemberantasan buta aksara merupakan program integral dalam pengentasan masyarakat dari kebodohan, kemiskinan, keterbelakangan dan ketidakberdayaan masyarakat dalam kerangka makro pengembangan kualitas sumber daya manusia.

Dalam beberapa dekade terahir dunia semakin peduli terhadap isu kemeleksaraan (literacy) khususnya pada kemampuan membaca dan menulis. Diyakini bahwa kemampuan ini akan mendorong individu memperoleh keuntungan atau kesempatan untuk berkontribusi di berbagai aspek kehidupan yang pada akhirnya akan memberi keuntungan secara kultural, sosial dan ekonomi.

Kepedulian atau kesadaran tersebut tercermin dalam deklarasi PBB tahun 1975 di Perpolis dan kemudian dilanjutkan di Hanburg pada tahun 1997. Dalam eklarasi Dakkar (Senegal:2000) mengenai Millenium Development Goals (MDGS) telah ditetapkan target yang nyata untuk tercapainya 50 persen peningkatan tingkat melek huruf orang dewasa pada tahun 2015 .

Di indonesia perhatian pemerintah terhadap pendidikan keaksaraan ditunjukkan dengan dikeluarkannya instruksi presiden RI no.5 tahun 2006 tentang Gerakan Nasional Pecepatan Pengentasan Warga Belajar Pendidikan Dasar (GNPPWBPD). Khusus mengenai buta aksara langkah kongkrit untuk pemantapan perencanaan program dimulai dengan mengadakan survei khusus yaitu survei buta aksara.

Berbagai kebijakan dalam upaya meningkatkan drajat kemeleksaraan penduduk telah dilakukan oleh pemerintah dari waktu ke waktu, baik dari program pendidikan dasar secara massal maupun melalui berbagai instrumen kebijakan seperti kursus A -B-C. Program pemberantasan buta huruf fungsional kejarpaket A dan saat ini yang paling populer yaitu melalui program keaksaraan fungsional yang dijalankan oleh pemerintah sejak tahun 1995. Program ini dimaksudkan untuk memberantas kebuta aksaraan dengan fokus kegiatan melalui diskusi, membaca, menulis, berhitung dan pemecahan masalah yang dihadapi dalam aktivitas yang berkaitan dengan kebutuhan keseharian. Kemampuan membaca dan menulis sejauh ini dapat diinterpretasikan, dan juga diukur dengan beberapa cara, serta mengalami penyesuaian dari waktu ke waktu. Pengertian melek huruf yang paling umum adalah kemampuan seseorang untuk dapat membaca dan menulis secara sederhana. Pengenalan terhdap angka (berhitung) sebetulnya hanya komplemen dari komponen 
pengukuran kebuta aksaraan/ buta huruf yang berlaku secara intrnasional.

Disadari sepenuhnya bahwa berbagai program pemerintah khususnya dalam hal memberantas buta huruf tidak mungkin dapat dilakukan secara efektif tanpa didukung oleh ketersediaan data dan statistik yang terpercaya. Berdasarkan data Badan Pusat Statistuk (BPS) menunjukkanbahwa konsentrasibuta aksara terutama berada di Parado, Kecamatan Parado Kabupaten Bima yaitu dan yang dikutip dalam aksara (2007:16).

$\begin{array}{ccc}\text { Dalam upaya } & \text { penuntasan } \\ \text { buta aksara tersebut } & \text { pemerintah }\end{array}$ Kabupaten Bima berkomitmen untuk meningkatkan sinergi, melakukan teroosan-terobosan baru guna meningkatkan pendidikan khususnya pada pendidikan orang dewasa karena pendidikan merupakan parameter penting yang merupakan salah satu idikator untuk menentukan Human Depelovement Index (HDI).

Berdasarkan data penduduk buta huruf dan program pendidikan keaksaraan fungsional kabupaten Bima tahun 2009/2010 jumlah penduduk yang masih tersisa (buta aksara) sebesar 58.606, angka tersebut masih tergolong tinggi dan sekitar 50 persen dianatranya berusia di atas 45 tahun. Kalau melihat angka ini banyak yang sinis mengatakan "Ah", biarkan saja buta aksara itu, kan usianya sudah tua-tua sepuluh, dua puluh tahun hilang sendiri”, (asumsi sebagianbesarmasyarakat). Anggapan demikian agaknya kurang manusiawi. Sebab fakta menunjukkan bahwa buta aksara berbanding lurus dengan kemiskinan dan keterbelakangan. (Prof. Bambang Sudibyo yang dikutif dalam Aksara 2006: 14).

Desa Parado Wane Kecamatan Parado termasuk sasaran program penuntasan buta aksara dan dalam mengimplementasikan program tersebut, maka Lembaga PKBM yang merupakan salah satu dari lembaga pendidikan luar sekolah yang ada di Desa Parado Wane telah bekerjasama dengan pemerintah desa melakukan pendataan penduduk dan pendidikan dari tanggal 12 sampai dengan 26 April dengan mengerahkan 20 orang petugas pendataan pada 11 (sebelas) rukun warga yang ada di Desa Parado Wane. Dari hasil pendataan tersebut terdapat penduduk usia 15-44 tahun yang buta aksara sebanyak 528 orang yang terdiri dari laki-laki 239 orang dan perempuan 289 orang $(9,60 \%)$ dari jumlah penduduk 5415 orang, dan data tersebut belum terhitung usia 45 tahun ke atas yang masih buta aksara.

Dengan demikian mereka yang sudah melek aksara bisa secara fungsional menggunakan bekal baca tulis tersebut untuk berkembang menjadi pekerja yang produktif, 
anggota masyarakat yang aktif dan efektif sertaanggotakeluarga yangbaik dan andal. Dampak sosial semacam itulah yang diharapkan sebagai hasil dari program keaksaraan.

Pendidikan keaksaraan merupakan salah satu bentuk layanan pendidikan non formal bagi masyarakat yang masih buta aksara di Indonesia.Pendidikan keaksaraan di selenggarakan untuk memberi layanan pendidikan yang memenuhi standar kelayakan mutu, proses, hasil dan dampak sehingga hasilnya dapat dipertanggung jawabkan.

\section{B. Rumusan Masalah, Tujuan dan Kegunaan Penelitian}

Berdasarkan uraian latar belakang masalah di atas, maka permasalahan penelitian di rumuskan sebagai berikut: 1. Bagaimana dampak pendidikan keaksaraan fungsional terhadap kualitas kehidupan sosial warga belajar?. 2. Bagaimana dampak pendidikan keaksaraan fungsional terhadap kualitas kehidupan ekonomi warga belajar?.Tujuan penelitian: 1. Untuk Mengetahui dampak pendidikan keaksaraan fungsional terhadap kualitas kehidupan sosial warga belajar di Desa Parado Wane Kecamatan Parado Kabupaten Bima. 2. Untuk Mengetahui dampak pendidikan keaksaraan fungsional terhadap kualitas kehidupan ekonomi warga belajar di Desa Parado Wane Kecamatan Parado Kabupaten Bima.
Kegunaan secara teoritis: Penelitian ini diharapkan dapat memberikan sumbangan teoritis yaitu bagi perkembangan ilmu Administrasi Negara khususnya bagi segenap mahasiswa yang tertarik untuk mengkajilebih dalam tentangDampak Pendidikan Keaksaraan Fungsional terhadap Peningkatan Kualitas dan Taraf Hidup Masyarakat. Kegunaan praktis: 1. Sebagai informasi bagi para pembina dan penyelenggara pendidikan keaksaraan dalam melakukan pembinaan terhadap kelompok-kelompok belajar keaksaraan yang dibinanya. 2. Sebagai masukan bagi para tutor / fasilisator pendidikan keaksaraan bahwa pola pembelajaran mempunyai andil dalam pencapaian hasil belajar warga belajar. 3. Sebagai masukan kepada pemerintah desa bahwa pendidikan keaksaraan mempunyai peran dalam pengembangan masyarakat. 3. Bagi masyarakat khususnya (warga belajar) dapat bermanfaat dalam kehidupan sosial ekonomi mereka yang berorientasi pada upaya pemecahan masalah.

\section{Metode Penelitian}

Pendekatan yang digunakan dalampenelitianiniadalahpendekatan kualitatif. Dimana dalam peneliti inimenghasilkan data-data yang berupa kata-kata tertulis atau lisan dari orang atau pelaku yang diamati. Peneliti menggunakan metode kualitatif disebabkan karena data 
yang ingin dicapai dalam penelitian ini adalah data-data hasil observasi. Disamping itu, peneliti ingin menggambarkan objek penelitian secara apa adanya atau yang bersifat alamiah. jenis yang digunakan peneliti adalah jenis penelitian Deskriptif kualitatif, dimana jenis penelitian deskriptif kualitatif ini digunakan untuk memberi gambaran atau melukiskan keadaan subjek atau objek penelitian pada saat sekarang berdasarkanfakta-faktayangnyata dan penelitian ini dilakukan dilapangan bukan di laboratorium.Penelitian ini dilakukan di Desa Parado Wane Kecamatan Parado Kabupaten Bima. Populasi adalah keseluruhan orang atau obyek yang akan diteliti.Prof. Dr. Sugiyono (2010) menegaskan bahwa terdapat perbedaan mendasar dalam pengertian antara "populasi dan sampel” dalam penelitian kuantitatif dan kualitatif. Dalam penelitian kuantitatif, populasi di artikan sebagai wilayah generalisasi yang terdiri atas: obyek/subyek yang mempunyai kualitas dan karakteristik tertentu yang diterapkan oleh peneliti untuk dipelajari dan kemudian ditarik kesimpulannya. Populasi itu misalnya penduduk di wilayah tertentu, jumlah guru dan murid di sekolah tertentu dan sebagainya. Populasi bukan hanya orang, tetapi juga obyek dan bendabenda alam yang lain. Populasi juga bukan sekedar jumlah yang ada pada obyek/subyek yang dipelajari, tetapi meliputi keseluruhan karakteristik/ sifat yang dimiliki oleh obyek/subyek itu.

Populasi dalam penelitian ini adalah masyarakat desa Parado Wane khususnya obyek yang bisa memberikan informasi tentang sejauh mana dampak pendidikan keaksaraan fungsional terhadap peningkatan kualitas hidup social dan ekonomi.F. Teknik pengumpulan data: Metode observasi adalah suatu metode penelitian untuk mendapatkan data-data dengan mengadakan pengamatan secara langsung dan mencatat gejala-gejala yang diselidiki. Metode observasi merupakan teknik pengumpulan data dengan menggunakan indera manusia di sertai dengan pencatatan secara sistematik penyelidik langsung mendatangi sasaran-sasaran penyelidikannya, mendengar, melihat serta membuat catatan-catatan (I.K. Natia, 1994: 48).

Observasi atau pengamatan meliputi kegiatan pemusatan perhatianterhadapsuatuobjekdengan menggunakan alat indra (Suharsimi, 1993: 128).Metode interview adalah proses tanya jawab atau percakapan dalam penelitian berlangsung secara lisan (Singarimbun, 1998: 195). Interview disebut juga wawancara atau kuisioner lisan, adalah sebuah dialog yang dilakukan oleh pewawancara (interviewer) untuk memperoleh informasi dari orang yang 
diwawancarai (responden) (Suharsimi, 1992: 126). Sedangkan menurut Moleong (2002: 135) menjelaskan bahwa wawancara adalah percakapan dengan maksud tertentu yang dilakukan oleh dua orang yaitu pewawancara dan narasumber, dari pendapat di atas dapat disimpulkan bahwa wawancara adalah sebuah dialog yang dilakukan dua orang yaitu pewawancara dan responden dengan maksud tertentu.Menurut I.K. Natia (1994) metode dokumentasi adalah metode penyelidikan untuk memperoleh keteranganketerangan atau informasi dari data usaha atau catatan-catatan tentang masalah-masalah atau peristiwa lalu. Dokumentasi, berasal dari kata dokumen, yang berarti barang-barang tertulis di dalam melaksanakan penelitian. Dalam metode dokumentasi, peneliti menyelidiki benda-benda tertulis seperti bukubuku, majalah, dokumen, peraturanperaturan, notulen rapat, catatan harian dan sebagainya (Suharsimi Arikunto, 1992: 131-132). Dengan menggunakan metode ini peneliti dapat memperoleh data tertulis dari lokasi dan subjek penelitian, dan metode ini sangat mendukung keaslian dan keabsahan data serta dapat menyesuaikan dan menulis data yang benar. Data yang diperoleh agar menggunakan metode ini adalah tentang sarana dan prasarana serta output dan kualitas output. Dokumen yang diperoleh dengan metode ini adalah dokumen tentang jumlah warga belajar, lokasi tempat warga belajar, data tentang identifikasi Desa Parado Wane. Teknik Analisis Data: dalam analisis data menurut Patton (1990: 268) adalah proses pengaturan urutan data, mengorganisasikannya ke dalam suatu pola, kategori dan satuan uraian dasar (Moleong, 2002: 103). Sedangkan Bogdad dan Taylor (1975: 79) mendefinisikan analisis data sebagai proses yang rinci. Usaha secara formal untuk menemukan tema dan merumuskan hipotesis (ide) seperti yang disarankan oleh data, dan sebagai usaha untuk memberikan bantuan pada tema hipotesis itu (Moleong, 2002: 103). intensif yaitu sesudah meninggalkan lapangan (Moleong, 2002: 104). Dalam penelitian ini, analisis datadatanya menggunakan teknik "Analisis Domein" dimana dilakukan terhadap data yang diperoleh dari pengamatan dan wawancara atau pengamatan deskriptif yang terdapat dalam catatan lapangan Moleong (2005: 2004). Adapun langkahlangkah yang dilakukan dalam analisis domein seperti berikut: 1 . Memilih salah satu hubungan simantik dari sembilan hubungan simantik yang tersedia hubungan termasuk spasial sebab akibat rasional, lokasi tempat bertindak, fungsi, alat tujuan dan urutan. 2. Menyiapkan lembar analisis domein. 3. Memilih salah 
satu sampel catatan lapangan yang dibuat terakhir untuk memulainya. 4. Mencari istilah acuan dan istilah bagian yang cocok dengan hubungan simantik dari catatan lapangan. 5. Mengulangi usaha pencarian domein sampai semua hubungan semantik habis (Moleong, 2005: 305).

\section{KAJIAN PUSTAKA}

\section{A. Pendidikan Keaksaraan Fungsional}

Secara lebih teknis, dapat ditegaskan mengenai pendidikan Keaksaraan, merupakan bentuk layanan PNF untuk membelajarkan masyarakat buta aksara, agar memiliki keterampilan baca tulis hitung, dan kemampuan fungsional untuk meningkatkan "mutu"dan "taraf" hidupnya . Keaksaraan dapat didefinisikan sebagai salah satu bentuk layanan Pendidikan Non Formal (PNF) bagi masyarakat yang belum memiliki kemampuan ca-listung, dan setelah mengikuti program ini (hasil belajarnya) mereka memiliki kemampuan "membaca menulis dan berhitung, mendengarkan dan berbicara" dalam bahasa Indonesia serta menggunakan / berfungsi bagi kehidupannya. Artinya mereka tidak hanya memiliki kemampuan keaksaraan dan keterampilan atau bermata pencaharian saja, tetapi juga dapat survive dalam dunia kehidupannya.
Definisi keaksaraan mengacu pada hasil deklarasi dari seminar di Toronto tentang literacy di negaranegara industri, seperti yang dikutip Gillespie (1990:17) merumuskan:

1. Literacy is a basic human right for advancement of people araund the world ( keaksaraan adalah hak asasi manusia untuk memajukan manusia di seluruh dunia );

2. Literacy is a major problem not only in develoving countries, but in indrustrialized contries well. It is a sign and affect, of poverty, unimployment, alienation and oppresive, social structur. Its effect both individual and communities ( keaksaraan adalah masalah utama yang tidak hanya terjadi di negara berkembang, tetapi juga di Negara industri. Hal ini menandai dan mempengaruhi kemiskinan, pengangguran, keterasingan, dan struktursosial, individu dan masyarakat);

3. Literacy is more than the ability to read, write and compute. The demands created by advancing technology require levels of knowledge, skills and undurstanding to achieved basic literacy. Literacy is means of acquiring the understanding and ability necessary to improve living and conditions ( keaksaraan lebih dari sekedar kemampuan membaca, menulis, dan berhitung. Kebutuhannya 
tercipta dari kemajuan teknologi yang membutuhkan tingkat pengetahuan, keterampilan dan pemahaman menguasai keaksaraan dasar. Keaksaraan berarti penguasaan pemahaman dan kemampuan yang dibutuhkan untuk meningkatkan kehidupan dan kondisinya);

4. Literacy is a way of building community. It promotes social and individual change, equality of opportunity and global understanding

(keaksaraan merupakan cara membangun masyarakat dengan mamajukan perubahan sosial dan individu, keaksaraan, kesempatan, dan pemahaman global);

5. Justice demands that the problem of literacy must ba attaked in a word that processes all the means and resources to do so (kebutuhan keadilan yang merupakan masalah keaksaraan harus dicapai dengan melaksanakan semua cara dan memanfaatkan sumber daya yang ada).

Berdasarkan pengertian diatas, keaksaraan merupakan hak asasi manusia untuk kemajuan masyarakat seluruh dunia.Buta aksara merupakan masalah utama, bukan hanya dinegara-negara berkembang tetapi juga dinegara industri.Hal ini merupakan dampak dari kemiskinan, pengangguran, pertikaian, tekanan, serta struktur sosial. Semua itu akan berdampak pada individu dan pada masyarakatnya. Keaksaraan tidak hanya sekedar kemampuan baca tulis hitung, tetapi juga dalam rangka memenuhikebutuhanyangdiciptakan oleh teknologi maju.Semua itu memerlukan pengetahuan, keahlian dan pemahaman sebagai upaya untuk mencapai keaksaraan dasar.

Menurut John Hunter (1997:124), ada tiga kategori dasar tentang definisi keaksaraan. Setiap kategori didasari oleh asumsi yamg sangat berbeda dari peran keaksaraan dalam kehidupan setiap individu dan dalam kehidupan masyarakat, yaitu:

1. Literacy as a set of basic skills, abilities, or competensies (keaksaraan merupakan seperangkat keterampilan dan kemampuan atau kompetensi dasar);

2. Literacyas thenecessary foundation for a higher quality of life (keaksaraan sebagai dasar yang penting untuk meningkatkan kualitas kehidupan yang lebih baik);

3. Literacy as areflection of political and structural realities (keaksaraan merupakan refleksi dari kebijakan dan kenyataan struktural).

Jadi, istilah keaksaraan menekankan pada suatu kemampuan untuk dapat mengatasi suatu kondisi 
baru yang tercipta oleh lingkungan masyarakat khususnya diperlukan dalam rangka agar warga belajar dapat memiliki kemampuan yang bermanfaat bagi diri dan masyarakat sekitarnya. Asumsi ini menekankan pada peningkatan kualitas hidup dan pemberdayaan masyarakat, disertai harapan bahwa melalui pendidikan keaksaraan akan dapat mengembangkan kemampuan dan keterampilan warga belajar, selanjutnya dapat digunakan untuk memecahkan masalah kehidupannya sendiri dan kehidupan masyarakat di sekitarnya, membuka jalan untuk mendapatkan sumber-sumber kehidupannya, melaksanakan kehidupan sehari-hari secara efektif dan efisien, mengunjungi dan belajar pada lembaga yang dibutuhkan, dan menggali, mempelajari pengetahuan keterampilan dan sikap pembaharuan untuk ikut berpartisipasi dalam pembangunan.

Sedangkan istilah fungsional dalam keaksaraan, berkaitan erat dengan minat dan kebutuhan warga belajar,fungsidantujuandilakukannya pembelajaran keaksaraan fumgsional, serta adanya jaminan bahwa hasil belajarnya benar bermakna atau bermanfaat ( fungsional ) bagi peningkatan mutu kehidupan warga belajar dan masyarakatnya.

Keaksaraan fungsional adalah suatu pendekatan atau cara untuk mengembangkan kemampuan seseorang dalam menguasai dan menggunakan keterampilan membaca, menulis, berhitung, mengamati dan menganalisis, yang berorientasi pada kehidupan seharihari serta memanfaatkan potensi yang ada di lingkungan sekitar (Samto, $2003 ; 9)$.

\section{Tujuan Pendidikan Kea- ksaraan}

Terdapat enam tujuan dari penyelenggaraan pendidikan keaksaraan, yaitu :

1) Membelajarkan masyarakat buta aksara (warga belajar) agar mampu membaca, menulis dan berhitung, serta berbahasa Indonesia;memiikipengetahuan dan keterampilan dasar yang benar - benar bermanfaat bagi peningkatan mutu dan taraf hidupnya.

2) Mengembangkan kemampuan warga belajar dalam memecahkan masalah sehari - hari yang dihadapi oleh mereka.

3) Melatih warga belajar untuk menggunakan keterampilan dan kompetensi keaksaraan dalam kehidupan sehari - hari.

4) Memotifasi warga belajar sehingga mampu memberdayakan dirinya sendiri dengan menggunakan kompetensi keaksaraan. 
5) Mengembangkan kemampuan berusaha atau bermata pencaharian sehingga mampu meningkatkan taraf hidupnya.

6) Mengembangkan kemampuan dan minat baca warga belajar sehingga mampu menjadi bagian dari masyarakat gemar membaca dan masyarakat belajar.

\section{Prinsip Pendidikan Keaksaraan}

Adapun prinsip-prinsip dari penyelenggaraan pendidikan keaksaraan, di Indonesia adalah sebagai berikut:

1) Kontekslokal,agarpembelajaran pendidikan keaksaraan dapat berjalan sesuai dengan fungsi dan tujuannya, maka bahan belajar harus digali dari konteks lokal. Bahan belajar harus bermanfaat bagi kehidupan wargabelajarsehari-hari.Mereka yang hidup di daerah perkotaan berbeda kebutuhannya dengan mereka yang hidup di daerah pertanian, nelayan, ataudaerah spesifik lainnya. Perlu dipahami kebutuhan warga belajar untuk mengembangkan program pembelajaran pendidikan keaksaraan yang benar-benar bermutu dan relevan.

2) Desain lokal, unsur-unsur pokok berkaitan penyajian pembelajaran pendidikan keaksaraan seperti : tujuan, kelompoksasaran, bahan belajar, sarana belajar, kegiatan belajar, waktu dan tempat pertemuan, dan unsur-unsurpentinglainnya, harus dirancang sesuai dengan situasi, dan potensi lokal di mana kelompok belajar berbeda. Perlu juga dibuat kesepakatan belajar, rencana pembelajaran, dan pemilihan kegiatan belajar atas dasar minat, kebutuhan, dan harapan kelompok belajar, serta dirancang sesuai karakteristik kelompok belajar.

3) Proses partisipatif, program pendidikan keaksaraan harus mampu memobilisasi warga belajar untuk melakukan beragam tindakan atau perbuatan sehingga dapat mengembangkan ragam keterampilan yang bermanfaat untuk memeperbaiki mutu kehidupan dan tarap hidup warga belajar. Pendidikan keaksaraan fungsional harus berorientasi pada tindakan, dan semua unsur yang terlibat di dalamnya harus secara aktif dan proaktif turut berpartisipasi dalam keseluruhan kegiatan.

4) Kesesuaian hubungan belajar, Program pendidikan keaksaraan seyogyanya dimulai dari halhal yang telah diketahui dan dapat dilakukan oleh warga belajar, sehingga pengalaman, kemampuan, minat, dan 
kebutuhan belajar mereka hendaknya menjadi dasar dalam menjalin hubungan yang harmonis dan dinamis antara tutor dengan warga belajar dalam kegiatan pembelajaran.

5) Fungsionalisasi hasil belajar, program pendidikan keaksaraan harus memberikan manfaat dan makna yang berkaitan secara langsung dengan lingkungan hidup, pekerjaan atau mata pencaharian, dan situasi keluarga warga belajar, sehingga hasil belajar warga belajar memberi manfaat bagi peningkatan mutu kehidupannya.

6) Kesadaran, proses pembelajaran keaksaraan hendaknya dapat meningkatkan kesadaran dan kepedulian warga belajar terhadap keadaan dan permasalahan lingkungan untuk melakukan aktivitas kehidupannya.

7) Fleksibilitas, program pendidikan keaksaraan harus fleksibel, agar memungkinkan untuk dimodifikasi sehingga responsif terhadap minat dan kebutuhan belajar serta kondisi lingkungan warga belajar yang berubah dari waktu ke waktu.

8) Keanekaragaman, program pendidikan keaksaraan hendaknya bervariasi dilihat dari segi materi, metode maupun strategi pembelajarannya sehingga mampu memenuhi minat dan kebutuhan belajar warga belajar di setiap daerah yang berbeda-beda.

\section{Standar Kompetensi Keaksaraan}

Dasar

Standar Kompetensi Keaksaraan Dasar (selanjutnya disingkat SKK Dasar) para program pendidikan keaksaraan merupakan seperangkat kemampuan keaksaraan dasar yang harus dikuasai oleh warga belajar. Kemampuan keaksaraan dasar tersebut meliputi kemampuan berbahasa (mendengarkan, berbicara, membaca, menulis dan berhitung) merupakan kemampuan yang dapat difungsikan dalam kehidupan seharihari.

Untuk mencapai SKK Dasar tersebut diperlukan standar kompetensilulusan yang dapat dicapai melalui standar kompetensi dan kompetensidasar.Standar kompetensi dan kompetensi dasar (SK-KD) dapat diukur melalui indikator-indikator yang harus dikuasai oleh warga belajar.Sedangkan yang dimaksud dengan standar kompetensi lulusan (SKL) adalah kualifikasi kemampuan lulusan yang mencakup pengetahuan, sikap, dan keterampilan.

Lalu yang dimaksud dengan standar Kompetensi adalah ukuran kompetensi minimal yang harus dicapai warga belajar setelah mengukuti suatu proses 
pembelajaran pada satuan pendidikan tertentu. Sedangkan yang dimaksud kompetensi dasar keaksaraan dasar adalah seperangkat kemampuan minimal untuk mencapai standar kompetensi yang telah ditetapakan meliputi kemampuan mendengar, berbicara, membaca, menulis dan kemampuan berhitung dalam kehidupan sehari-sehari.

Ruang lingkup SK-SD adalah: 1) mendengar, 2) berbicara, 3) membaca, 4) menulis, 5) berhitung. Keseluruhan aspek di atas berhubungan dengan kehidupan sehari-hari dan bermakna bagi warga belajar.

SK-KD merupakan standar minimal yang harus dikuasai oleh warga belajar setelah mengikuti program pendidikan keaksaraan dasar. Tujuan SK_KD berbahasa dan berhitung ini adalah agar warga belajar: a) memahami bahasa indonesia dan menggunakannya dengan tepat dan kreatif untuk bertujuan dalam kehidupan seharihari, b) menggunakan bahasa indonesia untuk meningkatkan pengetahuan serta kematangan emosional dan sosial, c) memahami konsep berhitung dan meerapkannya dalam kehidupan sehari-hari.

\section{Standar Keaksaraan Usaha Mandiri}

Kompetensi usaha mandiri bertujuan untuk : a)meningkatkan kemampuan keberaksaraan yang terkait dengan usaha mandiri uantuk mengembangkan dan mengaktualisasikan berbagai potensi yang dimiliki warga belajar, b) meningkatkan keberdayaan warga belajar melalui peningkatan pengetahuan, sikap, keterampilan, dan berusaha secara mandiri, c) mengembangkan kemampuan berusaha atau bermata pencaharian sehingga mampu meningkatkan mutu dan taraf hidup warga belajar, dan d) mengembangkan kemampuan dan minat baca warga belajar sehingga mampu menjadi bagian dari masyarakat gemar membaca dan masyarakat belajar.

SKKUM mencakup Standar Kompetensi Lulusan (SKL), Standar Kompetensi (SK), Kompetensi Dasar (KD), dan Indikator. Adapun standar kompetensilulusannya, adalah sebagai berikut:

1) Mengidentifikasi jenis-jenis usaha yang berpeluang untuk dikembangkan sesuai potensi lingkungan dan pasar.

2) Menuliskan dan mengomunikasikan rancangan usaha mandiri yang akan dikembangkan.

3) Menguasai kerempilan produksi tertentu sesuai dengan uasaha yang dikembangkan.

4) Memasarkan produk usaha yang dikembangkan. 
5) Melakukan analisa perhitungan laba/rugi dari uasaha yang dikembangkan.

6) Menjalin kemitraan dalam rangka pengembangan dan kelangsungan uasaha.

7) Memelihara dan mengembangkan kompetensi membaca, menulis, dan berkomunikasi dengan bahasa indonesia secara berkelanjutan dalam menjalankan kegiatan uasaha.

Keaksaraan fungsional merupakan sebuah pendekatan melalui program pendidikan non formal untuk mengatasi masyarakat yang menyandang buta aksara.Keaksaraan fungsional diartikan secara sederhana sebagai kemampuan untuk membaca, menulis dan berhitung (calistung) serta berorientasi pada kehidupan sehari-hari dengan memanfaatkan kearifan lokal dan sumber daya alam yang ada di lingkungan sekitar untuk meningkatkan mutu dan taraf hidup warga belajarnya.

Keaksaraan fungsional membantu masyarakat lebih berdaya dengan cara belajar untuk menambah kemampuan dan pengetahuan. Penyandang buta aksara dalam kehidupan seharihari akan dihadapkan pada dilema dan masalah yang sangat komplek. Seperti, kesulitan mendampingi dan membantu dalam menyelesaikan tugas sekolah anaknya di rumah. Penyandang buta aksara (buta huruf) dapat dianggap negatif di lingkungan sekitar yang berdampak pada psikologisnya karena adanya kesenjangan dalam status sosial pada baca, tulis dan berhitung mengenai angka dan bukan hanya pada menghitung uang saja.Penyandang buta aksara juga memiliki keterbatasan tidak dapat membaca dan menulis untuk mengurus administrasi kependudukan, seperti pembuatan KTP (Kartu Tanda Penduduk). Proses mendapatkan akses pengurusan jaminan kesehatan masyarakat dengan prosedur membuat keterangan keluarga miskin kepada aparatur pemerintah terendah yaitu Rukun Tetangga (RT) sampai dengan tingkatan teratas juga termasuk keterbatasan penyandang buta aksara. Proses tersebut dapat dilihat ketika mereka harus mengisi absensi pertemuan atau kegiatan dilingkungan. Fakta tersebut, terlihat bahwa penyandang buta aksara kurang memiliki kesempatan dengan kata lain mereka haruslah bergantung kepada orang lain. Adanya program keaksaraan fungsional, penyandang buta aksara memiliki kekuatan untuk meningkatkan mutu dan kualitas hidupnya dalam kehidupan seharihari.

Jumlah penyandang buta aksara di Indonesia memang dapat dikatakan masih besar, hal ini dapat dilihat 
dari data Kementerian Pendidikan Nasional (Kemendiknas) tahun 2011 mengenai penduduk Indonesia yang buta huruf (penyandang buta aksara usia 15 tahun ke atas sebanyak 7,76 juta orang. Sebanyak $64 \%$ atau 6,3 juta dari data Kemendiknas adalah perempuan masih menyandang buta aksara yang berusia 15 tahun ke atas (Kemendiknas, 2011).

Kemampuan baca tulis pada kenyataannya masih menjadi permasalahan bagi sebagian rakyat Indonesia khususnya perempuan miskin. Berdasarkan identifikasi data dilapangan, di kota Banjarmasin sendiri tercatat 1,760 penyandang buta aksara. Data Diknas Kota Banjarmasin tahun 2011, dari jumlah penduduk Kota Banjarmasin yang buta huruf (penyandang buta aksara) usia 15 tahun ke atas ada sebanyak sebanyak 1.553 orang. (Disdik Kota Banjarmasin: 2011).

Secara umum kegiatan pembelajaran keaksaraan fungsional dasar dari pengelola di Parado Wane selama ini yang berusaha menerapkan critical literacy sebagai bentuk upaya memenuhi Standar Kompetensi Keaksaraan Dasar (SKKD). Ruang lingkup SKKD sesuai dengan ketentuan Kemendiknas yang terdiri dari 5 pokok, yaitu,

1) Mendengar

2) Berbicara

3) Membaca
4) Menulis

5) Berhitung. Ternyata dalam penerapannya masih belum efektif

Sepenuhnya terakomodasi dalam kegiatan pembelajaran yang dilakukan, hal ini terbukti dengan masih adanya warga belajar yang berulang-ulang mengikuti program keaksaraan fungsional tersebut.

Kegiatan pembelajaran yang masih konfensional membutuhkan waktu dan pemahaman yang berat dan lama dari warga belajar untuk mencapai SKKD tersebut.Karena itu perlu dilakukan pengembangan metode dan media pembelajaran yang lebih efektif untuk membantu peningkatan pemahaman warga belajar dalam kegiatan belajarnya secara tutorial.Metiode ini dapat di aplikasikan dengan pengembangan media Pembelajaran Papan Casing. Casing singkatan untuk Cantol, CalistungdanGasing, yangmerupakan pengembangan media pembelajaran dengan mengaplikasikan antara metode belajar membaca dan aksara mencantol, media Poster/ beberan, papan tulis, Kartu huruf dan Angka, serta Game/ permainan tradisional yang berkompilasi antara permainan rakyat dan pembelajaran Calistung tersebut. 


\section{Prinsip}

Program

Fungsional

Penyelenggaraan

program

keaksaraan fungsional menggunakan empat prinsip utama yang perlu diperhatikan adalah :

1) Konteks lokal, artinya kegiatan belajar mengajar yang dilaksanakan, berdasarkan pada minat dan kebutuhan peserta didik, serta potensi yang ada disekitarnya. Kontek lokal mengacu pada konteks sosial lokal dan kebutuhan khusus di setiap peserta didik dan masyarakat sekitarnya. Tutor bersama peserta didik melakukanobservasilingkungan sekitar untuk mencari dan mengumpulkan informasi untuk pengelolaan kegiatan pembelajaran. Observasi lingkungan bertujuan untuk mengidentifikasi minat dan kebutuhan serta menemukan masalah yang dihadapi mereka.

2) Desain lokal, tutor bersama peserta didik perlu merancang sendiri kegiatan belajarnya di kelompok belajar berdasarkan minat, kebutuhan, masalah, kenyataan, dan potensi tempat penyelenggaraan program keaksaraan fungsional. Rancangan pembelajarannya bersifat fleksibel, mudah dimodifikasi, diganti, dan ditambah. Tutor bersama peserta didik merancang dan menetapkan kurikulum sendiri. Proses penyusunan didesain pembelajaran bisa dilakukan melalui diskusi antara tutor dengan peserta didik untuk menetapkan:

a. Pokok Bahasan yang ingin dipelajari dan tujuannya

b. Prioritas pokok bahasan yang diinginkan;

c. cara atau strategi pembelajaran yang akan digunakan

d. langkah-langkah kegiatan yang perlu dilakukan, agar tujuan pembelajaran tercapai

e. Jadwal kegiatan pembelajaran; dan

f. kesepakatan belajar dan mengajar.

3) Proses partisipatif, dilakukan dengan menyusun perencanaan, pelaksanaan, dan evaluasi penyelenggaraan program keaksaraan fungsional. Strategi partisipatif diimplementasikan dengan cara melibatkan semua pihak, termasuk tutor dan peserta didik aktif dalam setiap tahap kegiatan pembelajaran. Kegiatan partisipatif dapat dilakukan oleh tutor dengan amemberikan stimulasi terhadap peserta didik untuk berdiskusidengan cara membuat pertanyaan, melakukan 
wawancara tentang pengalaman peserta didik, menulis cerita lokal, membuat peta masalaha lingkungan, membuat gambar, dan sebagainya.

4) Fungsionalisasi hasil belajar, kriteria utama dalam menentukan keberhasilan program keaksaraan fungsional adalah dengan cara meningkatkan kemampuan dan keterampilan setiap peserta didik dalam memanfaatkan dan memfungsikan keaksaraan atau hasil belajarnya dalam kegiatan sehari-hari sehingga mereka dapat meningkatkan mutu dan taraf hidupnya.

6. Tolak Ukur Keberhasilan Program Keaksaraan Fungsional

Orientasi Program Keaksaraan fungsional adalah membantu peserta didik agar memiliki kemampuan baca-tulis-hitung (calistung) dan mengembangkan kemampuan fungsional yang dibutuhkan dalam kehidupan sehari-hari. Dalam buku Penyelenggaraan Program Keaksaraan Fungsional, Direktoran Jenderal Pendidikan Luar Sekolah dan Pemuda, Direktorat Jenderal Tenaga Teknis (200: 11) dikemukakan kemampuan peserta didik yang menjadi tolak ukur keberhasilan program keaksaraan fungsional meliputi:
1) Kemampuan funsional untuk keperluan individu

2) Kemampuan fungsional untuk membantu anak-anaknya

3) Kemampuan fungsional untuk aktualisasi diri

4) Kemampuan fungsional berkaitan dengan pekerjaan warga belajar

5) Kemampuan fungsional berkaitan dengan sosial kemasyarakatan

6) Kemampuan fungsional berkaitan dengan pendidikan

7) Kemampuan fungsional berkaitan dengan pengelolaan kelompok belajar; dan

8) Kemampuan fungsional berhitung berkaitan dengan kehidupan sehari-hari.

\section{Pengelolaan Pembelajaran Keaksaraan fungsional}

Pengelolaan atau pengaturan pembelajaran keaksaraan fungsional pada dasarnya ada dua macam yaitu: pengelolaan edukatif, merupakan kegiatan penataan persiapan, pelaksanaan pembelajaran dan pelaksanaan penilaian, dan pengelolaan administratif. Sedangkan prinsip pengelolaan pembelajaraan keaksaraan fungsional adalah:
a. Menyeluruh terhadap aspek pengelolaan edukatif dan administrative
b. Memiliki nilai yang berarti 
c. Konsisten

dan berkesinambungan

d. Dilaksanakan secara partisipatif; dan

e. Menumbuhkan sikap inisiatif dan kreatif untuk mempercepat pencapaian tujuan akhir pembelajaran.

Ada tiga proses pengelolaan pembelajaran keaksaraan fungsional sebagai berikut :

1. Persiapan Pembelajaran

a. Identifikasi kemampuan awal keaksaraan calon peserta didik, sekaligus menjaring kebutuhan belajar dan potensi pendukungnya.

b. Mengelompokan calon peserta didik

c. Mengelompokan kebutuhan belajar apa yang paling dibutuhnkan berdasarkan potensi yang ada

d. Penyusunan program belajar.

\section{Pelaksanaan Pembelajaran} Langkah pembelajaran

a. Pelajari kembali SAP yang telah disusun

b. Mengabsen peserta didik

c. Pembelajaran dilakukan tahap demi tahap

d. Mencatat perkembangan calistung peserta didik

e. Melakukan penilaian setiap akhir pembelajaran

\section{Administrasi Pembelajaran}

Administrasi pembelajaran meliputi administrasi yang mendukung proses belajar mengajar dan kegiatan program pendukung keaksaraan fungsional yaitu :

a. Administras Peserta didik, daftar kecakapan awalnya, perkembangan diisi setiap pertemuan

b. catatan harian, dan buku kamus peseta didik.

c. Administrasi tutor, matrik gagasan pembelajaran, program pembelajaran seluruh topik, kesepakatan pembelajaran, satuan acara pembelajaran, absensi, dan buku penilaian hasil belajar peseta didik.

d. Administrasi lainnya, hasil karya peserta didik seperti korang dinding, poster abjad, dan lainlain.

3. Pengembangan

Media Pembelajaran Keaksaraan Fungsional

Dalam bidang Pendidikan Non-Formal pada umumnya dan Pendidikan Keaksaraan khususnya, sebenarnya sudah sejak lama dikenal adanya kriteria yang harus dipatuhi dalam prosedur penyusunan pengembangan media atau bahan belajar. Kriteria tersebut lebih dikenal istilah 7-M, yaitu:

1. Mudah; artinya mudah membuatnya, mudah 
memperoleh bahan dan alatnya, serta mudah menggunakannya.

2. Murah; artinya dengan biaya sedikit, jika memungkinkan bahkan tanpa biaya, media pembelajaran tersebut dapat dibuat.

3. Menarik; artinya menarik atau merangsang perhatian warga belajar (peserta pembelajaran), baik dari sisi bentuk, warna, jumlah, bahasa maupun isinya.

4. Mempan; artinya efektif atau berdayaguna bagi warga belajar (peserta pembelajaran) dalam memenuhi kebutuhannya.

5. Mendorong; artinya isinya mendorong warga belajar (peserta pembelajaran) untuk bersikap atau berbuat sesuatu yang positif, baik untuk dirinya sendiri maupun lingkungannya sesuai tujuan belajar yang diharapkan.

6. Mustari; artinya tepat waktu, isinya tidak basi, dan sesuai dengan kebutuhan dan potensi lokal/sekitar tempat pembelajaran.

7. Manfaat; artinya isinya bernilai, mengandung manfaat, tidak mubazir atau sia-sia, apalagi merusak.

Adapun langkah-langkah penyusunan dan pengembangan media pembelajaran keaksaraan fungsional ini juga mengacu pada kriteria tersebut. Penyusunan media pembelajaran dapat diartikan menciptakan media pembelajaran yang baru atau belum pernah ada, sedangkan pengembangan media pembelajaran dapat diartikan sebagai upaya mengadaptasi, merekayasa, atau menyesuaikan (modifikasi) media pembelajaran yang sudah ada dengan kebutuhan dalam proses pembelajaran.

Dalam proses pembelajaran seringkali tidak dilengkapi dengan media pembelajaran yang memadai. Oleh karena itu, pendidik (tutor/ fasilitator) ataupun pengelola/ penyelenggara program dituntut untuk mampu merancang, menyusun atau mengembangkan media pembelajaran efektif yang dapat digunakan dalam proses pembelajaran yang dikelolanya (Sujarwo. 2012).

\section{B. Kualitas Hidup dan Indikator Sosial Ekonomi}

1. Pengertian Kualitas Hidup

Kelangsungan hidup atau kualitas hidup merupakan persoalan yang penting dalam perekonomian danpengtahuan politik. Kualitashidup dapat diukur berdasarkan faktor sosial dan ekonomi. Bagian yang terpenting adalah kehidupan yang standar seperti jumlah uang, pelayanan dan akses terhadap barang yang dimiliki oleh seseorang.Jumlah darihal-hal tersebut mudah untuk diukur, namun hal lain 
seperti, kebebasan, kebahagiaan, seni, kesehatan, lingkungan dan inovasi merupakan hal yang lebih sulit untuk diukur. Istilah kualitas hidup, akademisi dan spesialis cenderung memisahkan istilah "kualitas dan hidup".

Kualitas merupakan suatu kondisi tertentu memeperbaiki atau mempeburuk, mengangkat atau menurunkan. Sedangkan arti dari hidup mencakp kondisi lingkungan tertentu.

Menurut Goetschdan Davist dalam Tjiptono (2005:10) menjelaskan bahwa kualitas merupakan kondisi yang dinamis yang berhubungan dengan produk, Sumber Daya Manusia, proses, dan lingkungan yang memenuhi ataumelebhi harapan.

Menurut W. Edwards deming

kualitas berarti pemecahan masalah untuk .mencapai penyempurnaan terus menerus

Menurut Iso kualitas didefinisikan sebagai derajat atau tingkat karakteristik yang melekat pada produk yang mencukupi persyaratan atau keinginan.

Menurut WHO Quality Of Life (QOL) didefinisikan sebagai persepsi individu terhadap posisi mereka dalam kehidupan, dalam konteks budaya dan sistem nilai dimana mereka hidup dan dalam kaitannya dengan tujuan mereka, harapan, standar dan keprihatinan.
Pengertian dari kualitas hidup atau Quality of Life (QOL) bermacam macam. Ini memberikan aspek psikologis bahwa seseorang itu sangat penting, meskipun beberapa macam varian ditemukan dengan subjektivitas individu. Prinsipnya ini meliputi penilaian yang sangat teliti dari hal yang bersifat umum (dengan perbedaannya) diantara pilihan pilihan, opini opini, prilaku dan nilai nilai oleh para peneliti merupakan arti yang padat. Dengan cara ini model dari kualitas hidup dikembangkan dengan mencerminkan nilai masing masing bersama pilihan dan harapan, pada waktu yang sama, mengkombinasikan kondisi hidup dan statistik dari alam tradisional.

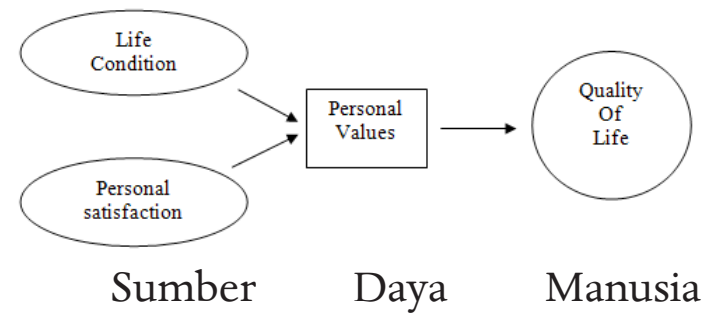
merupakan potensi yang terkandung dalamdirimanusiauntukmewujudkan perannya sebagai makhluk sosial yang adaftif dan transformatif yang mampu mengelola dirinya sendiriserta seluruh potensi yang terkandung di alam menuju tercapainya kesejahteraan kehidupan dalam tatanan yang seimbang dan berkelanjutan. Masalah sosial merupakan kondisi yang perlu diubah dan diperbaiki, sedangkan pembangunan masyarakat merupakan suatu usaha atau suatu proses untuk melakukann perubahan 
ke arah perbaikan. Pengembangan kualitas Sumber Daya Manusia (SDM) sebagai suatu proses pembudayaan bangsa bertujuan untuk meningkatkan kualitas manusia Indonesia yang menguasai pengetahuan, keterampilan, keahlian serta wawasan yang sesuai dengan perkembangan IPTEK. Wawasan yang diperlukan adalah kemampuan untuk memandang jauh ke depan, wawasan mutu dan kekaryaan serta wawasan inovasi dan perubahan yang sesuai dengan nilai dan sikap yang berkembang dalam masyarakat. (Djojonegoro, 1998 : 111) dalam Dr. H. Sufyarahma,. M.M.Pd (2003 : 30)

Pendidikan keaksaraan fungsional merupakan bentuk layanan Pendidikan Non Formal (PNF) bagi masyarakat yang bertujuan untuk meningkatkan mutu dan taraf hidup. Pendidikan masyarakat merupakan suatu proses dimana upaya pendidikan yang diprakarsai pemerintah diwujudkan secara terpadu untuk meningkatkan kondisi sosial, ekonomi dan budaya yang lebih bermanfaat dan memberdayakan masyarakat..

2. Indikator Kualitas Hidup Sosial dan Ekonomi

Peningkatan kualitas dapat diukur berdasarkan indikator sosial ekonomi. Menurut Organition of Economic and Culture Develpment (OECD:198). Indikator kualitas hidup adalahpendapatan perumahan, lingkungan, stabilitas sosial, kesehatan dan kesempatan kerja. Namun pada lingkup Pendidikan Non Formal hal ini lebih terbatas pada tingkat kemampuan keberdayaan masyarakatnya, dalam artian pencapain masyarakat yang mandiri (mampu membantu diri mereka sendiri) atau berswadaya, kreatif dan mampu mengadopsi inovasi. Melalui pendidikan keaksaraan fungsional warga belajar dapat meningkatkan mutu dan taraf hidupnya.

Sehingga dalam hal ini Quality Of Life didefinisikan sebagai persepsi apa yang dilakukan orang (dalam hal ini kebijakan pemerintah) dengan apa yang diberikan (warga belajar) sehingga pada akhirnya akan mengubahkualitashidup, apakahakan menjadi lebih baik atau sebaliknya, mengangkat atau menurunkan.

Dalam hal ini melalui kemampuan fungsional harapan pemerintah warga belajar dapat meningkatkan derajat dalam kehidupan sosial ekonomi. Kemampuan fungsional warga belajar dalam menggunakan keterampilan membaca, menulis dan berhitung dalam kehidupan sehari-hari. Kemampuan fungsional yang dimaksud adalah kemampuan warga belajar dalam menggunakan ketrampilan membaca, menulis dan berhitung dalam kehidupan seharihari. Kemampuan fungsional seperti, menulis nama dan alamat sendiri, 
membaca resep, membaca aturan minum obat, menghitung harga, membuat daftar belanja, menulis kuitansi, menulis dan membaca surat, membaca petunjuk, dan sebagainya (Depdikbud 1998 : 02). Menurut definisi Unesco Kemampuan baca tulis fungsional sebagai kemampuan keaksaraan fungsional (funcional literacy), adalah jika penduduk dapat terlibat dalam aktifitas dimana kemampuan keaksaraan merupakan prasyarat sebagai effective function kelompok atau masyarakatnya dan sebagai dasar dirinya untuk meningkatkan kemampuan membaca, menulis dan berhitungnya sendiri.Sehingga Kemampuan baca tulis fungsional dapat diartikan sebagai suatu kemampuan seseorang dalam memanfaatkan ketrampilan membaca, menulisnya dalam kehidupan sehari-hari ( Direktorat Pendidikan Masyarakat, 2003 : 1 ) sehingga menjadi manusia yang mandiri. Kemandirian manusia menurut Kantor Menteri Kependudukan dan Lingkungan Hidup (dalam Widodo 1990:3) dapat dilihat dari beberapa dimensi yaitu (1) bebas, dalam arti tumbuhnya tindakan atas kehendak sendiri dan bukan karena orang lain, dan bahkan tidak tergantungpadaoranglain(2)progresif dan ulet, seperti tampak pada usaha mengejar prestasi, penuh ketekunan, merencanakan dan mewujudkan harapannya (3) berinisiatif, yang berarti mampu berfikir dan bertindak secara rasional, kreatif dan penuh inisiatif (4) pengendalian dari alam, adanya kemampuan untuk mengatasi masalah yang dihadapi, mampu mengendalikan tindakannya serta kemampuan mempengaruhi lingkungan atas usahanya sendiri dan (5) kemantapan diri (Self-Esteem, SelfConfidence), mencakup aspek percaya diri pada diri sendiri dan memperoleh kepuasan atas dirinya sendiri.

Sehingga dengan demikian jika hal tersebut terwujud maka kualitas hidup sosial ekonomi akan menjadi lebih baik dan meningkat dari sebelumnya.

a. Indikator kualitas hidup sosial

$\begin{array}{ccr}\text { Konsepsi } & \text { kualitas hidup } \\ \text { diidentifikasikan } & \text { menjadi dua }\end{array}$ perspektif indikator (1) sosial indikator, merupakan penelitian yang dilakukan untuk nilai kebutuhan masyarakat (warga belajar) kualitas penelitian konvensional hidup, yang mempelajari apa yang orang inginkan dalam rangka meningkatkan kualitas hidup mereka yang dikutip dalam (Mukherji 2004:1). Sehingga hal ini dapat difokuskan pada hubungan antara unsur unsur subyektif dan objektif keadaan ketika mendefinisikan kualitas hidup. Elemen subyektif terdiri dari" rasa, subyektif kesejahteraan dan pengembangan pribadi, pembelajaran ,"pertumbuhan atau dikenal dengan kualitas orang / pengembangan 
pribadi. Kondisi objektif terdiri dari "kesempatan untuk eksploitasi oleh orang yang hidup "kehidupan atau dikenal sebagai kualitas kondisi”.

Pengukuran kualitas hidup sosial meliputi manusia sebagai diri pribadi dan sebgai anggota keluarga serta mayarakat, kualitas hidup sosial meliputi prilaku dan peran sosial yang mencakup 3 hal: 1) peran meliputi norma-norma yang dihubungankan dengan posisi atau tempat seseorang dalam masayarakat (peraturan yang membimibing seseorang dalam kehidupan kemasyarakatan), 2) peranan adalah suatu konsep tentang apa yang dapat dilakukan olehindividu dalam masyarakat sebagai organisasi, 3)perananjugadapatdikatakansebagai prilaku individu yang penting bagi struktur sosial (Soedjono Soekanto, 1990 : 244) yang berfungsi untuk meningkatkan investasi dan kinerja seseorang, keaksaraan seperti halnya gizi, kesehatan, (yang mencakup pola hidup sehari-hari) menciptakan lingkungan dan masyarakat terpelajar, mengembangkan kemampuan kongnitif untuk membaca dunia (kesadaran kritis dari kesadaran naif warga belajar) pada intinya minimal mereka dihargai sebagaimana layaknya manusia.

b. Indikator Kualitas Ekonomi

Sedangkan padabidangekonomi meliputi warga belajar dalam kehidupannya dapat meningkatkan kesejahteraan (kepuasan hidup) yang meliputi pekerjaan, pendapatan, sehingga dapat survive dalam kehidupannya, bersikap ekonomis dan berdaya saing sehingga tujuan akhir dari pendidikan keaksaraan adalah pihak penerima (sasaran didik) mampu berfungsi dalam kehidupan ekonomi (Bhola; 1994.32 dalam Kusnandi).Berkembang menjadi pekerja ,bagi yang berusia produktif , sehingga mepunyai pendapatan dan dapat memenuhi kebutuhan dan kelangsungan hidup yang lebih baik.

Dengan demikian mandat sosial yang diemban oleh pendidikan keaksaraan bukan sekedar untuk mengantarkan penyandang buta aksara menjadi melek aksara tetapi sampai pada literate functioning (melek aksara yang termanfaatkan secara fungsional). Hal ini bersifat relatif, dimana makana sosialnya bisa bervariasi antara bangsa yang satu dengan bangsa lainnya tapi makna esensialnya sama yaitu mereka yang sudah memperoleh pengetahuan dan baca tulis menjadi bisa memanfaatkannya dan memperaktikannya secara fungsional dalam kehidupan sehari-hari bagi keperluan perbaikan kualitas hidup di lingkungan sosial ekonomi dan budaya mereka masing-masing.

Sebagaiana Bingman, Ebert dan Bell (1997) dalam Sanafiah Faisal (2006:2) menawarkan empat hasil yangsepatutnya bisa dcapai melalui pendidikan keaksaraan, yaitu: 
1. Sosio economic well being (jobs, income, survival)

Ekonomi sosial menjadi lebih baik ( pekerjaan, pendapatan dan kelangsungan hidup.

2. Social well being ( family and communiti life )

Kehidupan sosial yang lebih baik (kehidupan keluarga dan masyarakat)

3. Personal well being (self esteem, life satisfaction)

Kehidupan pribadi yang lebih baik (penghargaan diri dan kepuasanhidup)

4. Physical well being (health and access to health care)

Jasmaniyangbaik(kesehatan dan kepedulian terhadap kesehatan)

Namunperlu diingatbahwa pada pendidikan orang dewasa (andragogi) berbeda dengan pendidikan pada anak anak (paedagogi), karena orang dewasa memiliki konsep diri artinya memiliki harga diri, status, kemampuan mengatur dirinya, anutan atau pandangan hidup seperti agama,budaya atau cita cita.Pola pemikirannya berdasarkan hubungan sebab akibat sehingga mempunyai analisis yang tinggi,oleh karena itu sangat perlu Iklim belajar yang bersifat kondusif sesuai dengan konteks sosial dan kebutuhan warga belajar. Karena pendidikan orang dewasa bersifat multi level.

\section{Karateristik Kualitas Lingkungan Hidup}

Secara sederhana kualitas lingkungan hidup diartikan sebagai keadaan lingkungan yang dapat memberikan daya dukung optimal bagi ke langsungan hidup manusia pada suatu wilayah. Kualitas lingkungan dicirikan antara lain dari suasana yang membuat orang merasa betah atau kerasan tinggal di tempatnya sendiri. Berbagaikeperluan hidup terpenuhi dari kebutuhan dasar atau primer, meliputi makan, minum, perumahan, sampai kebutuhan rohani atau spiritual meliputi pendidikan, rasa aman, dan sarana ibadah.Kualitas lingkungan hidup dapat dibedakan berdasarkan karakteristik biofisik, sosial-ekonomi, dan budaya.

\section{a. Lingkungan Biofisik}

Lingkungan biofisik adalah lingkunganyangterdiriataskomponen biotik dan abiotik yang berhubungan dan saling memengaruhi satu dengan lainnya.Komponen biotik merupakan makhluk hidup, seperti hewan, tumbuhan, dan manusia. Adapun komponen abiotik terdiri atas benda-benda mati, seperti tanah, air, udara, dan cahaya matahari. Kualitas lingkungan biofisik disebut baik jika interaksi antarkomponen berlangsung dengan seimbang.

\section{b. Lingkungan Sosial-Ekonomi}

Lingkungan sosial ekonomi adalah lingkungan manusia dalam 
hubungannya dengan sesama untuk memenuhi kebutuhan hidupnya. Standar kualitas lingkungan sosialekonomi disebut baik jika kehidupan manusia akan kebutuhan sandang, pangan, papan, pendidikan, dan kebutuhan hidup lainnya dapat terpenuhi.

\section{c. Lingkungan Budaya}

Lingkungan budaya adalah segala kondisi baik berupa materi (benda) maupun nonmateri yang dihasilkan manusia melalui aktivitas dan kreativitasnya. Lingkungan budaya dapat berupa bangunan, peralatan, pakaian, senjata, dan juga termasuk nonmateri, seperti tata nilai, norma, adat istiadat, kesenian, dan sistem politik. Standar kualitas lingkungan budaya dikatakan baik jika di lingkungan tersebut dapat memberikan rasa aman dan sejahtera bagi semua anggota masyarakatnya dalam menjalankan dan mengem bangkan sistem budayanya.

Hal lain yang tidak kalah penting untuk diketahui di dalam memahami kualitas lingkungan adalah daya dukung lingkungan (carryingcapacity). Daya dukung lingkunganadalah ukuran kemampuan suatu lingkungan mendukung sejumlah kumpulan atau populasi jenis makhluk hidup tertentu untuk dapat hidup dalam suatu lingkungan tertentu. Lingkungan tersebut dapat berupa sebidang lahan, wilayah tertentu, atau ekosistem tertentu. Misalnya, lahan pertanian sawah, perkebunan, hutan, rawa, sungai, danau, pantai, desa, kota, permukiman, dan kawasan industri. Adapun sejumlah individu atau kelompok tertentu dapat berupa tumbuh-tumbuhan, binatang, ataupun manusia.Jika membahas mengenai individu atau kelompok manusia, maka yang dimaksud daya dukung lingkungan di sini adalah ukuran kemampuan suatu lingkungan mendukung sejumlah individu atau kelompok manusia untuk dapat hidup dengan wajar dalam lingkungan tersebut.

Lingkungan yang ada di sekitar manusia sangatlah beragam, begitu pula dengan daya dukung lingkungannya. Pada lingkungan yang berbeda maka akan memiliki daya dukung yang berbeda pula. Daya dukung lingkungan tidak mutlak, tetapi berkembang sesuai faktor atau sumber daya yang memengaruhinya, antara lain faktor geografi dan sosialbudaya. Adapun yang dimaksud dengan faktor-faktor geografi dan sosial budaya di antaranya sebagai berikut.

a. Faktor geografi, seperti iklim, kesuburan tanah, dan erosi.

b. Faktor sosial-budaya, seperti ilmu, pengetahuan, dan teknologi.

Daya dukung lingkungan sangat berkaitan erat dengan kepadatan (densitas) suatu populasi atau jumlah 
makhluk hidup yang terdapat dalam suatu lingkungan tertentu. Dengan mengetahui daya dukung atau kemampuan lingkungan dalam mendukung populasi di atasnya, dapat dihitung kemampuan tertinggi (maksimal) lingkungan tersebut. Berapakah yang dapat didukung lingkungan yang bersangkutan agar sejumlah makhluk hidup (populasi) dapat hidup dengan wajar.

Tingkat kepadatan dapat dikelompokkan menjadi tiga macam, yaitu sebagai berikut.

a. Tingkat kepadatan maksimum (tertinggi).

b. Tingkat kepadatan optimum (cukup/sedang/wajar).

c. Tingkat kepadatan berlebih (kelebihan populasi).

Kepadatan populasi mencapai tingkat berlebih jika kepadatannya melebihi kepadatan yang mampu didukung. Dapat dikatakan juga bahwa lingkungan telah sampai kepada batasnya sehingga pada saat yang bersamaan akan terjadi masalah lingkungan atau ketimpangan ekologi.

Jumlah manusia sampai saat ini terus bertambah dan berkembang. Adapun permukaan bumi yang merupakan ekosistem kehidupan manusia luasnya tetap. Hal ini akan mengakibatkan terjadinya benturan antara pertumbuhan jumlah manusia dan daya dukung lingkungan, pada akhirnya menimbulkan masalah lingkungan atau ketimpangan ekologi. Manusia dengan kemampuan ilmu, pengetahuan, dan teknologi dapat meningkatkan daya dukung lingkungan. Melalui penerapan teknologi dalam bidang pertanian, peternakan, dan permukiman, manusia dapat mengembang kan serta meningkatkan daya dukung lingkungan sehingga mampu memakmurkan kehidupan penduduk. Sebagai contoh, dengan diterapkannya program intensifikasi pertanian oleh pemerintah, maka satu hektar sawah yang sebelumnya hanya mampu menghasilkan satu ton gabah padi dapat menjadi dua atau tiga ton gabah padi.

Akibat dari kemajuan ilmu pengetahuan dan teknologi manusia pun dapat menurunkan daya dukung lingkungan bahkan dalam waktu singkat sampai kepada batas kemampuannya.Sumber daya lingkungan yang seharusnya berperan menopang kehidupan manusia atau makhluk hidup lainnya tidak lagi mampu mendukung kelangsungan kehidupannya.Maka yang terjadi adalah sebuah bencana baik alam maupunkemanusiaan.Dalamekologi, manusia dikenal sebagai makhluk paling dominan (man ecological dominant).Artinya, manusia sangat mampu memanfaatkan ling kungan bagi kesejahteraan hidupnya.Oleh karena kemampuan akalnya, saat 
ini manusia sangat berperan dalam menentukan alam dibandingkan makhluk lainnya. Alam atau lingkungan hidup akan lestari, serasi, atau hancur, semata-mata tergantung pada kemauan manusia itu sendiri.

\section{PEMBAHASAN HASIL PENELITIAN}

\section{A. Dampak Pendidikan Keaksaraan Fungsional Terhadap Kualitas Kehidupan Sosial Warga Belajar}

Tujuan pendidikan Keaksaraan Fungsional adalah warga belajar dapat meningkatkan mutu dan taraf hidup, sehingga akan berdampak terhadap berbagai bidang kehidupan mereka agarmenjadilebihbaikdanberkwalitas kehidupuan sosial ekonomi mereka agar menjadi lebih baik, karena kalau kita melihat bahwa mayoritas sasaran program keaksaraan adalah masyarakat miskin.

Dalam konteks pendidikan sepanjang hayat (life long education), tanggung jawab program keaksaraan tidak berhenti setelah program dinyatakan berakhir, namun harus sampai pada dampak pembelajaran bagi kehidupan mereka secara terus menerus sepanjang hidupnya. Adapan dampak pendidikan keaksaraan fungsional terhadap kualitas kehidupan sosial warga belajar meliputi tingkat keberhasilan masyarakatnya.

Pemberdayaan masyarakat perwujudan capacity building masyarakat yang bernuansa pada pemberdayaan sumberdaya manusia melalui pengembangunan kelembagaan pembangunan mulai dari tingkat pusat sampai tingkat pedesaan, memberdayaan masyarakat bertujuan mendidik masyarakat agar mampu membantu diri mereka sendiri. Tujuan yang akan diapai melalui usaha pemberdayaan masyarakat adalah masyarakat yang mandiri, berswadaya, kreatif dan mampu mengadopsi inovasi.

Pendidikan keaksaraan adalah upaya pembelajaran untuk menumbuhkan dan mengembangkan kemampuan membaca, menulis, menghitung dan berbahasa Indonesia dengan kandungan nilai fungsional bagi upaya peningkatan kualitas hidup dan penghidupan warga masyarakat atau bagi mereka yang memiliki kecakapan keaksaraan. Dalam arti luas setiap masyarakat yang berpendidikan pasti berwacana, yaitu berkomunikasi baca tulis, namun wacananya belum tentu berkualitas madani, literac' madani adalah kemampuan masyarakat untuk membaca agar mampu memberi keputusan sosial yang bertanggung jawab dan kemampuan menulis secara kitis untuk mengaktualisasikan peran sosialnya dalam masyarakat, membangun masyarakat madani yang merupakan ajang partisipasi (community empowerment) adalah 
warga negara sebagai bagian dari kehidupan demokrasi.

Perilaku masyarakat sangat menentukan keberlangsungan interaksi masyarakat tersebut dengan lingkungan, terutama menyangkut kondisi lingkungan tempat tinggal dan sebagainya. Adapun bentuk daripada prilaku masyarakat tersebut akan menentukan keberlangsungan interaksi yang terjadi namun dalam hal ini manusia (masyarakat) mempunyai peran dan menjadi faktor utama dalam interaksi tersebut.

Menurut penulis cara hidup manusia dipengaruhi oleh banyak faktor, begitu juga cara hidup yang ditunjukkanoleh sebagianmasyarakat Desa Parado Wane dipengaruhi oleh beberapa faktor yang terlibat dalam interaksi kehidupan, yaitu antara lain

a. Faktor jarak (pola pemukiman penduduk Desa Parado Wane) dapat berpengaruh terhadap keakraban, keseganan, rasa asing yang menimbulkan kesenjangan sosial dalam masyarakat.

b. Faktor status, status ekonomi (adanya golongan yang kaya dan miskin), status sosial (adanya golongan bawah, menengah, atas), status pendidikan (jenjang sekolah SD, SMP, SMA, Perguruan Tinggi) yang menimbulkan rasa rendah diri atau rasa tinggi hati yang menimbulkan dampak negatif dalam kehidupan masyarakat.

c. Faktor struktur(pola keruangan) yang masih menunjukkan adanya perbedaan individu dan kelompok dari warga yang dihadapkan pada suatu keadaan yang mempunyai peranan atau pengaruh yang kecil untuk diabaikan.

d. Faktorkepentingan, yaituadanya kelompok warga yang lebih mementingkan kepentingan diri sendiri atau mereka yang memperhatikan kepentingan orang lain atau kepentingan umum, juga akan mempunyai pengaruh terhadap tata kehidupan dengan lingkungan sekitarnya.

Sebagian besar perilaku masyarakat yang mempengaruhi lingkungan hidup dimulai dari pandangan hidup, nilai yang di anut, cara hidup sampai pada sistem aktivitas (penataan wadah tempat aktivitas tersebut berlangsung).

Melalui pendidikan Keaksaraan Fungsional segala kemungkinan dari cara pandang tersebut dapat diarahkan menjadi lebih baik menuju peradaban yang lebih maju, karena dalam pendidikan Keaksaraan Fungsionalbukanhanya terpaksa pada kemampuan baca tulis keaksaraan saja tetapi lebih kepada kelangsungan hidup yang lebih pada intinya mampu merubah pola pikir manusia sebagai 
diri pribadi, sebagai anggota keluarga dan masyarakat.

\section{B. Dampak Pendidikan Keaksaraan Fungsional Terhadap Kualitas Kehidupan Ekonomi Warga Belajar}

Dalam penyelenggaraan pendidikan keaksaraan, para warga belajarnya selain terlibat dalam proses calistungkom, mereka juga dilibatkan dalam pembelajaran vakasional, yang bertujuan untuk meningkatkan kemampuanmerekauntukmenguasai suatu bidang atau kemampuan yang dapat dipergunakan sebagai media untuk memperbaiki kondisi ekonomi keluarganya. Dampak pendidikan keaksaraan terhadap kualitas kehidupan ekonomi warga belajar adalah dapat dilihat berdasarkan berbagai tinjauan kehidupan ekonominya misalnya warga belajar sebagai pekerja, petani, buruh tani, pedagang, maupun sebagai ibu rumah tangga.

Pendidikan keaksaraan bukanlah untuk keaksaraan itu sendiri, namun lebih kepada dampak dan kebermaknaan bagi kehidupan mereka secara terus menerus sepanjang hidupnya, oleh karena itu cara pandang dan pola pembelajaran sangat berperan penting khususnya kesadaran bagipara Tutor Keaksaraan Fungsional dalam mengemban tugas sebagaiujungtombakdarikeberhasilan program pemerintah mencerdaskan kehidupan bangsa, menuju masyarakat madani. Normatifnya adalahwargabelajarsetelahmengikuti program Keaksaraan Fungsionalakan mengalami peningkatan terhadap berbagai bidang kehidupan sosial, budaya dan ekonomi contohnya peningkatan terhadap kesehatan, peningkatan terhadap perekonomian dan lain sebagainya.

\section{PENUTUP}

\section{A. Kesimpulan}

Dampak pendidikan Keaksaraan Fungsional terhadap kualitas kehidupan sosial ekonomi maka dapat disimpulkan bahwa, dengan adanya program pendidikan keaksaraan fungsional masyarakat Desa Parado Wane menjadi lebih berdaya, baik dalam kehidupan sosial maupun kehidupan ekonomi masyarakat Desa Parado Wane.

1. Dampak pendidikan keaksaraan fungsional terhadap kualitas kehidupan sosial adalah tercapai masyarakat yang mandiri dan beradab, masyarakatyang penuh ketekunan, dapat terwujudnya harapan-harapannya.

2. Mampu berpikir dan bertindak, mengendalikan dari dalam adanya kemampuan mengatasi masalah-masalah yang dihadapi, mempunyai keberanian dan tanggung jawab sosial yang tinggi, seperti adanya peningkatan terhadap bidang 
kesehatan masyarakat yang meliputi tingkat kematian bayi dan balita $0 \%$, jumlah balita dengan gizi baik mencapai $100 \%$, peningkatan angka harapan hidup, cakupan kepemilikan MCK. Bidang keamanan dan ketertiban masyarakat meningkat. Hal ini dapat dilihat melalui tidak ada konflik, perkelahian, pencurian dan perampokan, perjudian, kasus narkoba, prostitusi, pembunuhan, kejahatan seksual, kasus kekerasan dalam rumah tangga, penculikan, dan lain sebagainya. Bidang partisipasi masyarakat yang ditunjukkan dengan tingginya tingkat partisipasi masyarakat dalam hal pemilihan umum, MUSRENBANG, kegotongroyongan penduduk dan lain sebagainya, hal ini merupakan bentuk perwujudan masyarakat yang mempunyai kesadaran yang tinggi dalam berbagai aspek kehidupan sosial.

Dampak pendidikan keaksaraan fungsional terhadap kualitas kehidupan ekonomi adalah masyarakat Desa Parado Wane mampu meningkatkan mutu dan taraf hidup yang lebih baik seperti halnya cara pemenuhan kebutuhan. Melalui keterampilan yang dimiliki dan dapat dipergunakan dalam berbagai bidang kehidupan, seperti halnya warga belajar sebagai anggota keluarga, petani, buruh tani, pedagang, maupun sebagai ibu rumah tangga. Dengan demikian kualitas kehidupan, baik dalam lingkup sosial maupun ekonomi dikatagorikan menjadi lebih baik dan pada akhrnya akan berdampak terhadap peningkatan kualitas sumber daya manusia secara keseluruhan.

\section{DAFTAR PUSTAKA}

Agus Suwignyo. 2008. Pendidikan Tinggi Goncangan Perubahan. Penerbit PUSTAKA Pelajar Celeban Timur ult III/548 Yogyakarta.

Agus Pranoto Basuki, dkk. Program Pemberantasan Buta Aksara. Departemen Pendidikan Nasional Direktorat Jenderal Pendidikan Luar Sekolah Direktorat Pendidikan Masyarakat. 2005.

AgusRamdhani, S.Sos. dkk. Pendidikan

Keaksaraan dan Implementasi Pembelajarannya, porum Tutor Pendidikan Keaksaraan Provinsi Jawa Barat, Tahun 2009.

Bagong Suyanto Sutinah. Metode Penelitian Sosial, Berbagai Alternatif Pendekatan. Prenada Media Group. 2005. 
Ditjen PLS. Penyusunan Bahan Ajar. Departemen Pendidikan Nasional Direktorat Jenderal Pendidikan Luar Sekolah Direktorat Pendidikan Masyarakat. 2006.

Depdiknas. 2003. Pendidikan Keaksaraan dan Rencana Aksi Nasional. Depdiknas. Direktorat Pendidikan Masyarakat.

Kusnadi, M.Pd, dkk. Panduan Umum Pelatihan Program Pendidikan Keaksaraan.Departemen Pendidikan Nasional Direktorat Jenderal Pendidikan Luar Sekolah Direktorat Pendidikan Masyarakat. 2014.

Media Komunitas Pendidikan Keaksaraan AKSARA. PengembanganProgramPendidikan Keaksaraan, Edisi Mei-Juni 2007.

Prof. Dr. Bambang Sudibyo, MBA. Gerakan Nasional Percepatan Pemberantasan Buta Aksara. Departemen Pendidikan Nasional Direktorat Jenderal
Pendidikan Luar Sekolah Direktorat Pendidikan Masyarakat. 2006.

Pedoman Pelaksanaan Penyelenggaraan KF Inova Kreatif Model (32) Hari di NTB. Pemerintah Provinsi Nusa Tenggara Barat Tahun 2009.

Soerjono Soekanto. 1990. Sosiologi Suatu Pengantar, Devisi Buku Perguruan Tinggi. PT. Raja Grafindo Persada Jakarta.

Tim Pengembangan. Model Pembelajaran Partisipatif, Kelompok Program Keaksaraan Fungsional. Balai Pengembangan Kegiatan Belajar Masyarakat NTB. 2004.

Yusuf Ibrahim, 1990, Pengantar Metode Belajar Pendidikan Luar Sekolah : Jakarta PKB yagiri Lembang Bandung, Dirjen PLSP Depdikbud.

Yatim Riyanto, M.Pd. Metodologi Penelitian Pendidikan. Penerbit SIC. 2001. 